"Impact of splits on stock splits ratios around announcement day: empirical evidence from India"

\begin{tabular}{|c|c|}
\hline AUTHORS & $\begin{array}{l}\text { Anjali Gupta (D https://orcid.org/0000-0003-4227-327X } \\
\text { Purushottam Kumar Arya (D) https://orcid.org/0000-0003-3744-5508 }\end{array}$ \\
\hline ARTICLE INFO & $\begin{array}{l}\text { Anjali Gupta and Purushottam Kumar Arya (2020). Impact of splits on stock splits } \\
\text { ratios around announcement day: empirical evidence from India. Investment } \\
\text { Management and Financial Innovations, 17(3), 345-359. } \\
\text { doi:10.21511/imfi.17(3).2020.26 }\end{array}$ \\
\hline DOI & http://dx.doi.org/10.21511/imfi.17(3).2020.26 \\
\hline RELEASED ON & Tuesday, 06 October 2020 \\
\hline RECEIVED ON & Wednesday, 29 July 2020 \\
\hline ACCEPTED ON & Wednesday, 23 September 2020 \\
\hline LICENSE & $\begin{array}{l}(c)) E Y \\
\text { This work is licensed under a Creative Commons Attribution } 4.0 \text { International } \\
\text { License }\end{array}$ \\
\hline JOURNAL & "Investment Management and Financial Innovations" \\
\hline ISSN PRINT & $1810-4967$ \\
\hline ISSN ONLINE & $1812-9358$ \\
\hline PUBLISHER & LLC “Consulting Publishing Company "Business Perspectives" \\
\hline FOUNDER & LLC "Consulting Publishing Company "Business Perspectives" \\
\hline
\end{tabular}

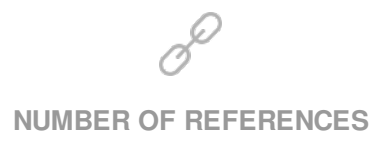

46
NUMBER OF FIGURES

4

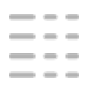

NUMBER OF TABLES

8

(C) The author(s) 2021. This publication is an open access article. 


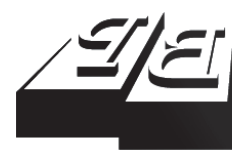

BUSINESS PERSPECTIVES

(O)

LLC "CPC "Business Perspectives" Hryhorii Skovoroda lane, 10, Sumy, 40022, Ukraine www.businessperspectives.org
Received on: $29^{\text {th }}$ of July, 2020 Accepted on: $23^{\text {rd }}$ of September, 2020 Published on: $6^{\text {th }}$ of October, 2020

(C) Dr. Anjali Gupta, Dr. Purushottam Kumar Arya, 2020

Dr. Anjali Gupta, Ph.D., M.Phil, M.Com., Assistant Professor Department of Commerce, Atma Ram Sanatan Dharma College, Delhi University, New Delhi, India.

Dr. Purushottam Kumar Arya, Ph.D. MBA, Assistant Professor, Department of Commerce, Atma Ram Sanatan Dharma College, Delhi University, New Delhi, India. (Corresponding author)

\section{IMPACT OF SPLITS ON STOCK SPLITS RATIOS AROUND ANNOUNCEMENT DAY: EMPIRICAL EVIDENCE FROM INDIA}

\begin{abstract}
Stock split should not have any impact on share prices, and there should be no value creation. The purpose of this study is to find any impact of stock splits announced in India between 1999 and 2019 on stock returns. The study aims to find differences in the impact of stock splits on stock returns with differences in stock split ratios. To examine the impact, the study includes 224 splits and adopts the standard event study methodology to find results. The presence of an abnormal return around split announcement day is the main factor, which determines the impact of stock split on the stocks. Average Abnormal Returns and Cumulative Average Abnormal Returns on percentage basis, z-test and p-value are used to statistically analyze the impact on stock prices around the announcement day of splits. These tests are used across different window periods (e.g., 20 days, 10 days and 5 days) around the event day (announcement day) to check if the impact of the event continues or decreases over time. The results point to a significant positive impact of stock splits on the returns of stock around the day the split was announced. The results also show that the impact is stronger for stock splits with ratios 10:1 (2.72 percent) and 10:2 (2.14 percent). It can be suggested that 10:1 and $10: 2$ are the most popular split ratios that receive maximum ongoing response to splits in the announcement window.
\end{abstract}

\section{Keywords}

announcement day, event study, abnormal returns, split factor, trading range

JEL Classification

G14, G10

\section{INTRODUCTION}

Stock split is a numeric change in the face value of shares that does not affect the investors' equity ownership. In theory, stock splits should not have any effect on share prices and should not create any value as a result. Despite theoretical simplicity, this corporate event has induced different reactions in many capital markets all over the world. Researchers identified many reasons for stock splits such as liquidity, signaling, neglected firm to name a few. The main motivation behind splits seems to be the Optimal Trading Range Hypothesis, which states that there is a price range in which trading of shares of a company is most favorable for that company. There is maximum liquidity in this range. If share prices are higher than this price range, managers decide to split shares to bring down share prices. Thus, stock split is done to maintain share prices in a favorable trading range and improve liquidity by facilitating trading of shares. According to Conroy and Harris (1999), when shares become quite costly, stock split is undertaken to move share prices to a suitable price range. The optimal trading range is considered a compromise between the desires of wealthy investors and institutions seeking a high price (to minimize brokerage costs) and the desires of small investors seeking a low price. 
This study is concerned about significant abnormal returns around the announcement. If the abnormal returns are positive, it means that the market views the split as a favorable event for future of the company, and vice versa. Splits are categorized based on the four most popular stock split ratios. The study also examines if there are differences in the impact of split announcements with differences in the split ratio.

\section{LITERATURE REVIEW}

Empirical research in the past has attempted to analyze this significant reaction around stock splits. According to Sharpe, Alexander, and Bailey (1995), a stock split entails a reduction of the par value of the corporation's shares and simultaneous exchange of the multiple numbers of new shares for each existing share. Brennan and Copeland (1988) used the transaction cost model around the announcement day of stock splits. According to the model, the trading cost depends on share prices; therefore, it is costly to trade at lower prices. According to the authors, the higher the split ratio, the higher the number of shares announced, the higher is the value of information conveyed by managers.

Lamoureux and Poon (1987) were of view that companies split shares to attain preferred trading range if share prices are abnormally high. Stock splits results in presence of new investors, broadens shareholders base and makes shares more affordable.

McNichols and Dravid (1991) state that executives decide to split when share prices deviate from that of other peers. Thus, the split factor ${ }^{1}$ is positively related to deviation from a normal price. The researchers were of the view that stock split can be reasonably regarded as a signaling indicator for small companies. According to them, the split factor signals splitting company's market value to investors, and managers choose a stock split ratio depending on private information about future performance they want to transmit to investors after considering price and market value of the shares. They tried to establish a relationship between the stock split ratio and earnings forecast. They believed that larger companies prefer a higher trading range. They added that the higher the share price before splitting, the more significant the stock split ratio.
Brennan and Hughes (1991) observed that a low split ratio signaled that companies were gearing for growth in the near future. The positive reaction of the market to stock split announcement and size of splits both indicate information. To test this, Ikenberry and Ramnath (2002) took splits with the split ratio of 2:1 on NYSE and ASE. They found that market reaction to stock splits was more significant for small companies, companies with low book to market ratio and companies splitting at depressed share prices.

Conroy and Harris (1999) found a positive relationship between AR, unexpected change in split ratio and proportional changes in earnings forecasts. They concluded that the split factor is announced if it is larger than expected than there are higher significant ARs. Kumar and Halageri (2013) examined share price reactions to stock split announcement and indicated that significant ARs are associated with stock splits. Suresha and Naidu (2013) using event study methodology tried to determine impact of stock splits. ARs were calculated using market model and $t$-tests were used to test their significance. They found significant positive ARs on announcement day (AD), but only for a short run .ARs did not persist and diluted to normal return. They concluded that Indian stock market reacts positively to stock splits. Singh and Supna (2013) examined stock splits in India in period 2006-07 to 2009-10 for a sample of 219 observations using event study methodology for calculating ARs. They found significant CAARs.

Xiao and Xuan (2013) studied the impact of stock splits announced by China's A-share companies. Using cross-sectional regression of ARs for announcement day, the authors showed that significant ARs were sensitive to the split ratio and market but not to the industry, company size and cash dividends.

Thus, researchers in the past believed that the split factor was used as a tool to signal the future performance of a company. No research has been

1 Split factor means the adjustment factor. For example, stock split with the split ratio of 2:1 means that the face value of the share is cut in half and the number of shares will double on ex-split day. 
conducted in India comparing and examining the differences in behavior of share prices for different stock split ratios. This analysis is undertaken to identify if there is any difference in the impact of stock splits with differences in stock splits ratios.

\section{AIMS AND HYPOTHESES}

The aim of this study is to examine the effect of stock splits on share prices. Another objective is to investigate differences in the effect of stock splits on share prices with differences in split ratios.

The research hypotheses tested in this study are:

\section{H1: Stock splits have an impact on share prices.}

H2: Stock split ratios have a different impact on share prices.

\section{DATA SOURCE AND RESEARCH METHODOLOGY}

Research papers and studies in the past have used an event study methodology to analyze the impact of stock splits on share prices. This study uses the event study methodology to determine whether an event generates abnormal returns after a company makes a financial decision concerning an asset or whether an event affects the value of that asset.

The sample for the analysis uses 224 stock splits announced by companies from January 1, 1999 to June 30, 2019. The sample companies have equity shares listed on the Bombay Stock Exchange (BSE). The sample companies are selected after considering the conditions such as clustering, overlapping and the absence of trading in respect to the announcement day for the total 1,392 stock splits announcements in the study period. The closing share prices data for the sample along with values of BSE Sensitive Index ${ }^{2}$ are collected from Prowess 19.1, a database of the Centre for Monitoring Indian Economy (CMIE) ${ }^{3}$.
The stock split announcement dates considered are not directly published in any of the leading business dailies. The dates of the announcement day are taken from the Prowess database, Capital line and press reports of Economic Times. Additional information is obtained from bseindia.com (official website of BSE).

Of the total sample, 202 companies are categorized based on the three most popular ${ }^{4}$ stock split ratios - 10:1 (70 companies), 10:2 (92 companies) and 10:5 (40 companies) in India.

To determine the presence or absence of differences in the influence of stock splits with differences in split ratios, AARs (Average Abnormal Returns) and CAARs (Cumulative Average Abnormal Returns) are calculated for groups with different stock split ratios.

The impact of stock splits around ${ }^{5}$ the announcement day is examined through abnormal returns (ARs) calculated using the market model as part of the event study. An abnormal return is defined as an actual return $\left(R_{i t}\right)$ minus a normal return $\left(N R_{i t}\right)$.

$$
A R_{i t}=R_{i t}-N R_{i t} .
$$

Normal return is calculated using the market model, which is as follows:

$$
R_{i t}=\alpha_{i}+\beta_{i} R_{m t}+\varepsilon_{i t}
$$

and

$$
N R_{i t}=\hat{\alpha}_{i}+\hat{\beta}_{i} R_{m t},
$$

where $R_{m t}$ is return on market index for day $t$, $\alpha_{i}$ measures mean returns not explained by the market, $\beta_{i}$ denotes sensitivity of returns (company $i)$ to market returns, and $\varepsilon_{i t}$ is the statistical error whose expectation is assumed to be zero.

2 BSE Sensitive index is a robust representative of the Indian stock market and is used as a proxy for the market portfolio as it is a value-weighted index that uses free-float market capital as value weights and is appropriate for the same type of analysis that Fama suggested.

3 CMIE is an independent private sector economic research organization. It has built the most extensive database on the Indian economy and companies in the form of databases and research reports. Academics and industries in India widely use it.

4 Most popular stock split ratios are the ones e in which the majority of companies in the period of study have split their shares.

5 Around here means an event window and includes an event day. 
Using equations (1) and (3), abnormal returns are defined as residuals or prediction errors of the model, which is as follows:

$$
A R_{i t}=R_{i t}-N R_{i t}=R_{i t}-\left(\hat{\alpha}_{i}+\hat{\beta}_{i} R_{m t}\right),
$$

where $\hat{\alpha}_{i}$ and $\hat{\beta}_{i}$ are OLS estimators of the regression coefficient estimated over the estimation window.

Impact on Average Abnormal Returns (AARs) announcement day

The un-weighted cross-sectional average abnormal returns in period $t$ are calculated:

$$
A A R_{i t}=\frac{\sum_{i=1}^{N} A R_{i t}}{N},
$$

where $N$ is the number of shares for which $A R$ are present on an event day in the event window. The event window is from $t_{-20}$ to $t_{+20}$. The null hypothesis tested is:

$$
H_{0}: E\left(A A R_{i t}\right)=0 .
$$

$Z$-test is used to test statistical significance of $A A R s$ on an event day. It assumes that $A A R$ s are independently and identically distributed, have the same mean and variances and are cross-sectionally uncorrelated. $\sigma$ is unknown, and the estimator of $\sigma$ can be constructed from cross-sectional variance of ARs in period $t_{i}$. $Z$-statistics is calculated as follows:

$$
Z=\sqrt{N}\left(\frac{A A R_{i t}}{s_{t}}\right) \approx N(0,1) .
$$

If AARs are not zero and statistically significant, this indicates that share prices behave positively or negatively to stock splits and affect wealth of shareholders.

This study tries to analyze a cumulative effect of AARs using Cumulative Average Abnormal Returns (CAARs). CAAR is obtained by aggregating AARs for the event day $t_{1}$ through $t_{2}$ using:

$$
C A A R_{i t}=\sum_{t=t_{1}}^{t_{2}} A A R_{i t} \text {. }
$$

The null hypothesis tested is that CAAR at the end of the period over which AARs are aggregated is zero. If CAAR is greater than zero, with significant $Z$-values, this means that stock splits have a significant impact on ARs.

To test statistical significance of CAAR for $N$ number of companies over $t$ days $\left(t_{1}\right.$ through $\left.t_{2}\right), Z_{c s}$ statistic is calculated at the $5 \%$ level of significance:

$$
Z_{c s}=\frac{1}{\sqrt{N \cdot T}}\left(\sum_{i=t_{1 i}}^{t_{2 i}} S A R_{i t}\right) .
$$

\section{RESULTS}

Impact on Average Abnormal Returns Announcement Day Figure 1 plots AARs for the announcement window from $t_{-20}$ to $t_{+20}$ and

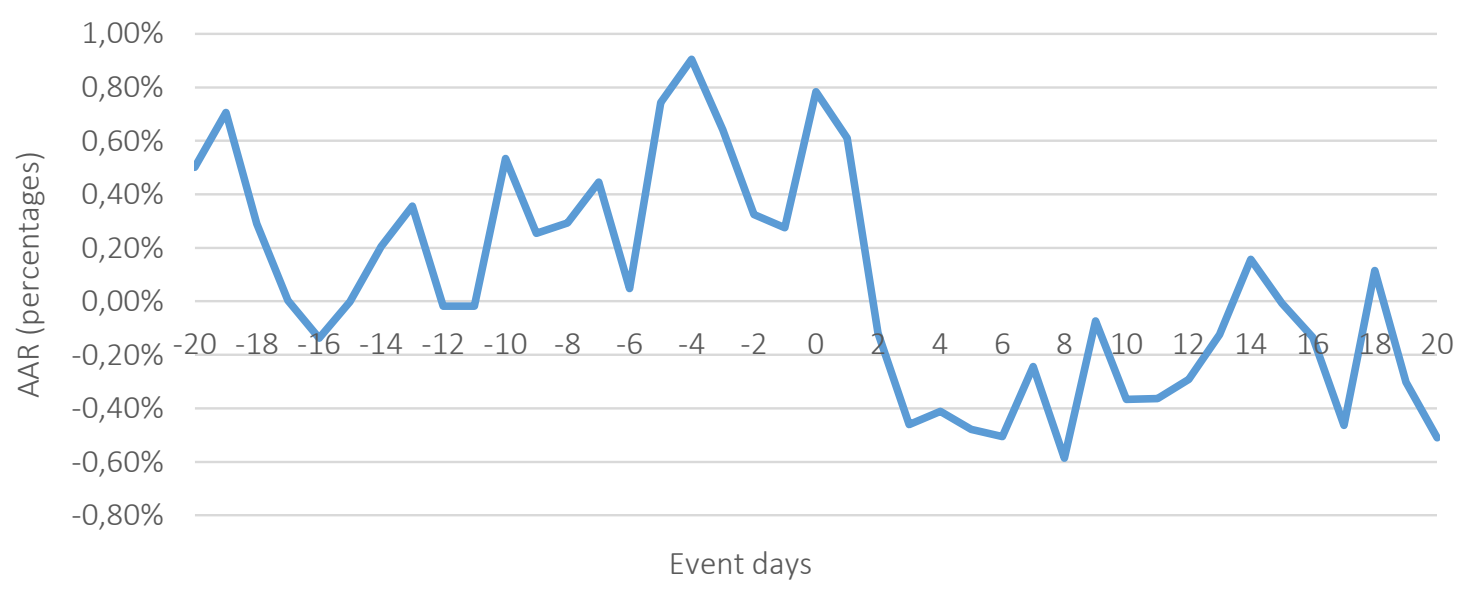

Figure 1. Average abnormal returns (announcement day) 
Table 1. Average abnormal returns (AARs) and Z-values (announcement day)

\begin{tabular}{|c|c|c|c|c|c|c|}
\hline Event day & AARs (\%) & $\begin{array}{c}\text { Standard } \\
\text { deviation (\%) }\end{array}$ & Z-values* & $\begin{array}{c}\text { Number of } \\
\text { positive ARs }\end{array}$ & $\begin{array}{c}\text { Number of } \\
\text { negative ARs }\end{array}$ & $\begin{array}{c}p \text {-values of the } \\
\text { Proportion Test* }\end{array}$ \\
\hline-20 & 0.50 & 3.62 & 2.03 & 106 & 108 & .946 \\
\hline-19 & 0.71 & 4.03 & 2.56 & 113 & 101 & .452 \\
\hline-18 & 0.29 & 4.00 & 1.06 & 96 & 118 & .151 \\
\hline-17 & 0.00 & 3.91 & 0.01 & 99 & 115 & .305 \\
\hline-16 & -0.14 & 3.28 & -0.61 & 88 & 126 & .011 \\
\hline-15 & 0.00 & 3.20 & -0.01 & 94 & 120 & .087 \\
\hline-14 & 0.21 & 3.74 & 0.80 & 110 & 104 & .733 \\
\hline-13 & 0.36 & 3.71 & 1.41 & 98 & 116 & .245 \\
\hline-12 & -0.02 & 3.72 & -0.07 & 97 & 117 & .194 \\
\hline-11 & -0.02 & 3.44 & -0.08 & 87 & 127 & .008 \\
\hline-10 & 0.53 & 3.38 & 2.32 & 125 & 89 & .017 \\
\hline-9 & 0.25 & 3.81 & 0.97 & 110 & 104 & .733 \\
\hline-8 & 0.29 & 3.38 & 1.27 & 111 & 103 & .632 \\
\hline-7 & 0.45 & 3.34 & 1.95 & 116 & 98 & .245 \\
\hline-6 & 0.05 & 3.40 & 0.21 & 106 & 108 & .946 \\
\hline-5 & 0.74 & 4.18 & 2.60 & 129 & 85 & .003 \\
\hline-4 & 0.91 & 4.04 & 3.28 & 111 & 103 & .632 \\
\hline-3 & 0.64 & 4.21 & 2.23 & 118 & 96 & .151 \\
\hline-2 & 0.32 & 3.70 & 1.28 & 105 & 109 & .838 \\
\hline-1 & 0.27 & 3.80 & 1.06 & 116 & 98 & .245 \\
\hline 0 & 0.78 & 4.09 & 2.80 & 125 & 89 & .017 \\
\hline+1 & 0.61 & 4.17 & 2.14 & 112 & 102 & .539 \\
\hline+2 & -0.12 & 3.39 & -0.51 & 96 & 118 & .151 \\
\hline+3 & -0.46 & 3.45 & -1.95 & 91 & 123 & .034 \\
\hline+4 & -0.41 & 3.73 & -1.61 & 92 & 122 & .047 \\
\hline+5 & -0.48 & 3.22 & -2.18 & 89 & 125 & .017 \\
\hline+6 & -0.51 & 3.11 & -2.38 & 84 & 130 & .002 \\
\hline+7 & -0.24 & 2.91 & -1.23 & 93 & 121 & .065 \\
\hline+8 & -0.59 & 3.21 & -2.67 & 82 & 132 & .001 \\
\hline+9 & -0.07 & 3.16 & -0.34 & 95 & 119 & .116 \\
\hline+10 & -0.37 & 2.98 & -1.80 & 93 & 121 & .065 \\
\hline+11 & -0.36 & 3.56 & -1.49 & 88 & 126 & .011 \\
\hline+12 & -0.29 & 3.10 & -1.38 & 98 & 116 & .245 \\
\hline+13 & -0.12 & 2.82 & -0.64 & 89 & 125 & .017 \\
\hline+14 & 0.16 & 3.05 & 0.76 & 107 & 107 & 1.00 \\
\hline+15 & -0.01 & 3.62 & -0.03 & 111 & 103 & .632 \\
\hline+16 & -0.13 & 3.48 & -0.56 & 96 & 118 & .151 \\
\hline+17 & -0.46 & 3.18 & -2.13 & 94 & 120 & .087 \\
\hline+18 & 0.11 & 3.23 & 0.52 & 109 & 105 & .838 \\
\hline+19 & -0.30 & 3.01 & -1.47 & 94 & 120 & .087 \\
\hline+20 & -0.51 & 3.39 & -2.21 & 85 & 129 & .003 \\
\hline
\end{tabular}

Note: * Values in bold are significant at the $5 \%$ significance level.

Table 1 shows that AAR on $t_{0}$ day is positive, with significant $Z$-value at the $5 \%$ level of significance. AARs on day $-t_{-20}$, $t_{-19}, t_{-10}, t_{-5}, t_{-4}, t_{-3}$ and $t_{+1}$ are positive and significant. AARs on day $t_{+5}, t_{+6}, t_{+8}, t_{+17}$ and $t_{+20}$ are negative with significant $Z$-values.

shows that AARs are positive before the announcement day of stock splits, in addition to an occasional descent to negative side on event days $t_{-17}$ and $t_{-16}$.

Table 1 shows AARs of the selected companies on and around the announcement day. It shows that in the 12-day event window from $t_{-10}$ till $t_{+1}$ day, there are positive AARs. After $t_{+1}$ day, majority of AARs are negative for the rest of the event window, except on day $t_{+14}$ and $t_{+18}$ when AARs are positive. The AAR on the announcement day is $0.78 \%$ (positive). AAR on $t_{-1}$ day is $0.27 \%$. On the announcement day, there is an increase in AAR by about 0.51 . On $t_{+1}$ day, AAR is $0.62 \%$, which means a decrease in AAR by about 0.16 . 
To check if there are a significant number of positive or negative ARs on a day in the event window, the equality of proportion test is performed. The null hypothesis tested is that the proportion of positive ARs is equal to the proportion of negative ARs on each day during the event window. Table 1 shows that the null hypothesis is rejected on 11 days $-t_{-16}, t_{-11}, t_{-10}, t_{+3}, t_{+4}, t_{+5}, t_{+6}, t_{+8}$, $t_{+11}, t_{+13}$ and $t_{+20}$, when the proportion of negative ARs is greater. On $t_{-5}$ and $t_{0}$ day, the proportion of positive ARs is greater and significant.

\subsection{Impact on Cumulative Average Abnormal Returns - Announcement Day}

The study tries to analyze a cumulative effect of AARs using cumulative average abnormal returns (CAARs).

Figure 2 plots CAARs over the 41-day event window and shows that after a rise in CAARs till the announcement day, the decline seems to be incessant till the end of the event window. This means that the market gradually learns about forthcoming stock split announcement.

Table 2 shows that CAAR of the selected companies gradually drifts up in the period from $t_{-20}$ to $t_{+3}$, after which it begins to decrease.
Table 2. CAARs and $Z_{c s}$-values (announcement day)

\begin{tabular}{|c|c|c|}
\hline Event day & CAAR (\%) & $Z_{c s}$-values* \\
\hline-20 & 0.50 & 0.42 \\
\hline-19 & 1.21 & 0.78 \\
\hline-18 & 1.50 & 0.91 \\
\hline-17 & 1.50 & 1.02 \\
\hline-16 & 1.36 & 0.90 \\
\hline-15 & 1.36 & 0.76 \\
\hline-14 & 1.57 & 0.96 \\
\hline-13 & 1.92 & 1.15 \\
\hline-12 & 1.90 & 1.23 \\
\hline-11 & 1.89 & 1.20 \\
\hline-10 & 2.42 & 1.50 \\
\hline-9 & 2.67 & 1.63 \\
\hline-8 & 2.97 & 1.79 \\
\hline-7 & 3.41 & 2.04 \\
\hline-6 & 3.46 & 2.23 \\
\hline-5 & 4.21 & 3.01 \\
\hline-4 & 5.11 & 3.57 \\
\hline-3 & 5.75 & 4.02 \\
\hline-2 & 6.08 & 4.23 \\
\hline-1 & 6.35 & 4.43 \\
\hline 0 & 7.14 & 5.09 \\
\hline+1 & 7.75 & 5.55 \\
\hline+2 & 7.63 & 5.38 \\
\hline+3 & 7.17 & 5.01 \\
\hline+4 & 6.75 & 4.76 \\
\hline+5 & 6.28 & 4.52 \\
\hline+6 & 5.77 & 4.09 \\
\hline+7 & 5.53 & 3.84 \\
\hline+8 & 4.94 & 3.35 \\
\hline+9 & 4.87 & 3.30 \\
\hline+10 & 4.50 & 3.13 \\
\hline+11 & 4.14 & 2.84 \\
\hline+12 & 3.85 & 2.59 \\
\hline
\end{tabular}

\section{CAAR}

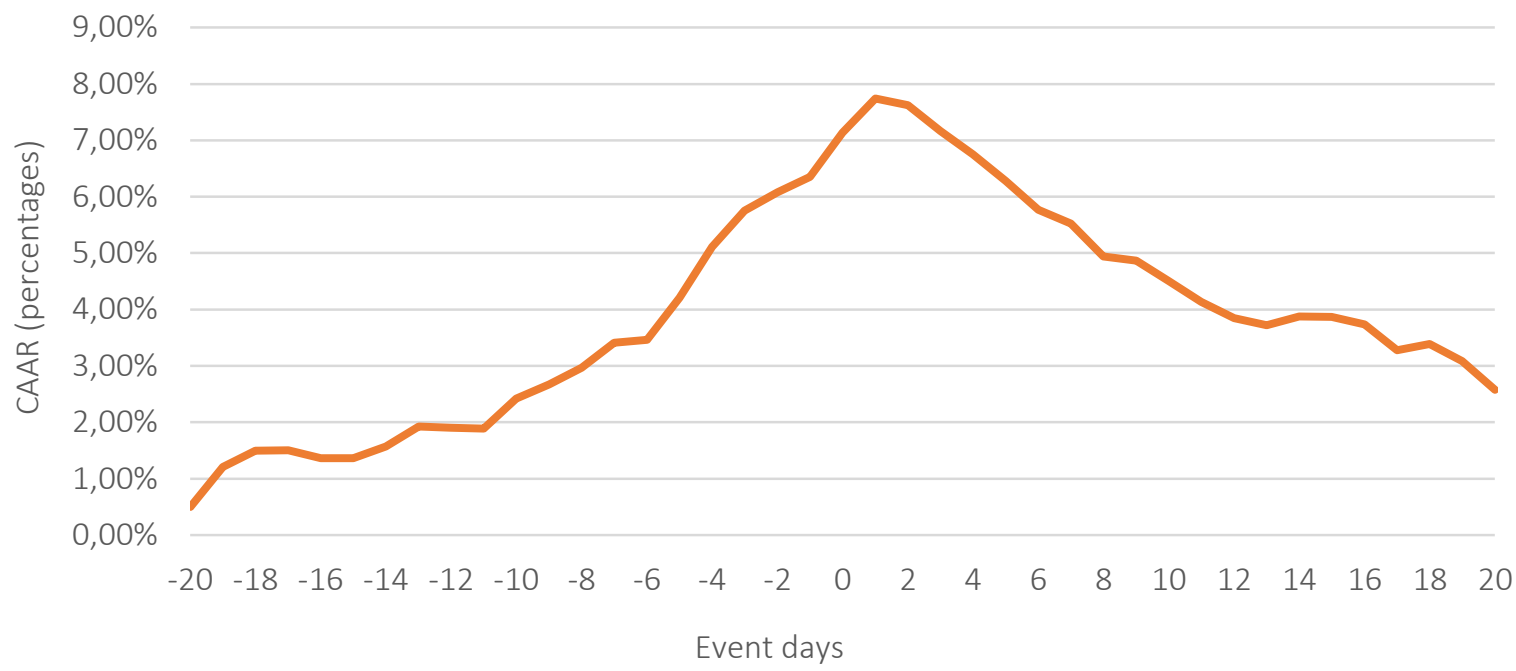

Figure 2. Cumulative average abnormal returns (announcement day) 
Table 2 (cont.). CAARs and $Z_{c s}$-values (announcement day)

\begin{tabular}{|c|c|c|}
\hline Event day & CAAR (\%) & $Z_{c s}$-values* \\
\hline+13 & 3.72 & 2.42 \\
\hline+14 & 3.88 & 2.42 \\
\hline+15 & 3.87 & 2.25 \\
\hline+16 & 3.74 & 1.92 \\
\hline+17 & 3.27 & 1.49 \\
\hline+18 & 3.39 & 1.44 \\
\hline+19 & 3.09 & 1.20 \\
\hline+20 & 2.58 & 0.89 \\
\hline
\end{tabular}

Note: * Values in bold are significant at the $5 \%$ significance level.

Table 2 shows that CAAR has significant $Z_{c s}{ }^{-}$ values starting from $t_{-7}$ day. CAAR is increastill day $t_{+3}$. After $t_{+3}$ day, the decline in CAARs seems to be incessant. CAAR has significant $Z_{c s}{ }^{-}$ values at $5 \%$ significance level for 23 days $\left(t_{-7}\right.$ day till $t_{+15}$ day).

\subsection{Impact on AAR - Announcement Day (different stock split ratios)} ing and continues to have significant $Z_{c s}$-values

in the announcement window. After $t_{+1}$ day, AARs start decreasing and are negative from $t_{+2}$ day for 19 days. Positive AARs with significant $Z$-value are noted on day $t_{0}$. Negative AARs with significant $Z$-value are observed on days $-t_{+6}$ and $t_{+8}$.

The number of positive ARs is greater, and negative ARs are less in the time period starting from $t_{-5}$ day and continues to be so till $t_{+1}$ day. The equality proportion test is conducted that checks the null hypothesis that the number of positive and negative ARs is equal. The null hypothesis is rejected at $5 \%$ significance level, and a significant increase in the number of negative ARs is observed for four days $-t_{-11}, t_{+4}, t_{+6}$, and $t_{+8}$. The null hypothesis is rejected, and a significant increase in the number of positive ARs is observed for three days $-t_{-1}, t_{0}$, and $t_{+1}$.

92 companies in the sample have announced stock splits in the ratio of 10:2.

Table 3 shows that AARs increase for six days start- Table 4 shows that there are positive AARs on days ing from day $t_{-4}$. This increase continues till $t_{+1}$ day $-t_{-5}, t_{-4}, t_{-1}$, and $t_{+1}$ with significant $Z$-values at

Table 3. AARs and Z-values - Announcement Day (split ratio 10:1)

Source: Calculated by the authors based on the Prowess IQ database.

\begin{tabular}{|c|c|c|c|c|c|c|}
\hline Event day & AAR (\%) & $\begin{array}{c}\text { Standard } \\
\text { deviation (\%) }\end{array}$ & Z-values* & $\begin{array}{c}\text { Number of } \\
\text { positive ARs }\end{array}$ & $\begin{array}{c}\text { Number of } \\
\text { negative ARs }\end{array}$ & $\begin{array}{l}p \text {-values of the } \\
\text { Proportion Test* }\end{array}$ \\
\hline-20 & 0.79 & 3.55 & 1.83 & 37 & 30 & .464 \\
\hline-19 & 0.86 & 3.84 & 1.83 & 36 & 31 & .625 \\
\hline-18 & 0.78 & 4.85 & 1.31 & 31 & 36 & .625 \\
\hline-17 & 0.06 & 4.36 & 0.12 & 32 & 35 & .807 \\
\hline-16 & -0.29 & 3.38 & -0.70 & 27 & 40 & .142 \\
\hline-15 & -0.05 & 3.08 & -0.14 & 29 & 38 & .328 \\
\hline-14 & 0.61 & 3.96 & 1.26 & 38 & 29 & .328 \\
\hline-13 & 0.35 & 4.52 & 0.63 & 31 & 36 & .625 \\
\hline-12 & 0.10 & 4.78 & 0.16 & 29 & 38 & .328 \\
\hline-11 & -0.20 & 4.22 & -0.40 & 23 & 44 & .014 \\
\hline-10 & 0.78 & 3.48 & 1.83 & 41 & 26 & .086 \\
\hline-9 & 0.73 & 4.80 & 1.24 & 36 & 31 & .625 \\
\hline-8 & -0.09 & 3.75 & -0.19 & 32 & 35 & .807 \\
\hline-7 & 0.26 & 3.68 & 0.59 & 32 & 35 & .807 \\
\hline-6 & -0.54 & 3.31 & -1.33 & 30 & 37 & .464 \\
\hline-5 & 0.84 & 5.31 & 1.29 & 41 & 26 & .086 \\
\hline-4 & 0.50 & 3.85 & 1.07 & 38 & 29 & .328 \\
\hline-3 & 0.55 & 4.33 & 1.05 & 39 & 28 & .222 \\
\hline-2 & 0.65 & 4.05 & 1.31 & 36 & 31 & .625 \\
\hline-1 & 0.48 & 3.80 & 1.04 & 42 & 25 & .050 \\
\hline 0 & 1.45 & 4.38 & 2.72 & 41 & 26 & .086 \\
\hline+1 & 0.66 & 4.11 & 1.31 & 36 & 31 & .625 \\
\hline
\end{tabular}


Table 3 (cont.). AARs and Z-values - Announcement Day (split ratio 10:1)

\begin{tabular}{|c|c|c|c|c|c|c|}
\hline Event day & AAR (\%) & $\begin{array}{c}\text { Standard } \\
\text { deviation (\%) }\end{array}$ & Z-values* & $\begin{array}{c}\text { Number of } \\
\text { positive ARs }\end{array}$ & $\begin{array}{c}\text { Number of } \\
\text { negative ARs }\end{array}$ & $\begin{array}{l}p \text {-values of the } \\
\text { Proportion Test* }\end{array}$ \\
\hline+2 & -0.06 & 3.20 & -0.16 & 29 & 38 & .328 \\
\hline+3 & -0.59 & 3.54 & -1.38 & 30 & 37 & .464 \\
\hline+4 & -0.59 & 4.27 & -1.14 & 25 & 42 & .050 \\
\hline+5 & -0.16 & 3.36 & -0.38 & 29 & 38 & .328 \\
\hline+6 & -0.98 & 2.60 & -3.10 & 19 & 48 & .001 \\
\hline+7 & -0.51 & 3.00 & -1.38 & 28 & 39 & .222 \\
\hline+8 & -0.95 & 3.52 & -2.22 & 24 & 43 & .027 \\
\hline+9 & -0.11 & 2.98 & -0.30 & 33 & 34 & 1.00 \\
\hline+10 & -0.08 & 2.58 & -0.25 & 31 & 36 & .625 \\
\hline+11 & -0.01 & 4.01 & -0.01 & 32 & 35 & .807 \\
\hline+12 & 0.01 & 3.84 & 0.02 & 30 & 37 & .464 \\
\hline+13 & 0.00 & 2.75 & -0.01 & 32 & 35 & .807 \\
\hline+14 & -0.49 & 3.11 & -1.30 & 29 & 38 & .328 \\
\hline+15 & -0.37 & 3.71 & -0.82 & 32 & 35 & .807 \\
\hline+16 & -0.27 & 3.37 & -0.66 & 32 & 35 & .807 \\
\hline+17 & 0.17 & 3.18 & 0.43 & 39 & 28 & .222 \\
\hline+18 & 0.10 & 3.19 & 0.25 & 33 & 34 & 1.00 \\
\hline+19 & -0.04 & 3.40 & -0.10 & 31 & 36 & .625 \\
\hline+20 & -0.63 & 2.71 & -1.90 & 25 & 42 & .050 \\
\hline
\end{tabular}

Note: * Values in bold are significant at the $5 \%$ significance level.

the $5 \%$ significance level. There are negative AARs on day $t_{+5}$ with significant $Z$-value at the $5 \%$ significance level.

The null hypothesis that the proportion of positive and negative AARs is equal is not accepted, and significant $p$-values are present for three days $-t_{-17}, t_{-11}$, and $t_{+5}$ (proportion of negative ARs is greater compared to positive ARs ). The proportion of positive ARs is greater in contrast to negative ARs with significant $p$-value on $t_{-5}$ day.
There are 40 companies that have announced stock splits in the ratio of 10:5. Table 4 shows that AARs increase consistently and are positive for four days, from $t_{-4}$ to $t_{+1}$. Positive AAR with significant $Z$-value is observed only for $t_{-19}$ day.

Table 5 sows that the null hypothesis that the proportion of positive and negative ARs is equal is not rejected in the announcement window for the split ratio 10:5.

Table 4. AARs and Z-values - Announcement Day (split ratio 10:2)

Source: Calculated by the authors based on the Prowess IQ database.

\begin{tabular}{|c|c|c|c|c|c|c|}
\hline Event day & AARs (\%) & $\begin{array}{c}\text { Standard } \\
\text { deviation (\%) }\end{array}$ & Z-values* & $\begin{array}{c}\text { Number of } \\
\text { positive ARs }\end{array}$ & $\begin{array}{c}\text { Number of } \\
\text { negative ARs }\end{array}$ & $\begin{array}{l}p \text {-values for the } \\
\text { Proportion Test* }\end{array}$ \\
\hline-20 & -0.06 & 3.39 & -0.17 & 37 & 49 & .235 \\
\hline-19 & 0.07 & 4.26 & 0.16 & 38 & 48 & .332 \\
\hline-18 & -0.04 & 2.77 & -0.13 & 34 & 52 & .066 \\
\hline-17 & -0.01 & 3.42 & -0.02 & 33 & 53 & .040 \\
\hline-16 & -0.13 & 2.93 & -0.42 & 36 & 50 & .161 \\
\hline-15 & -0.07 & 2.25 & -0.31 & 38 & 48 & .332 \\
\hline-14 & 0.35 & 2.82 & 1.14 & 44 & 42 & .914 \\
\hline-13 & 0.44 & 3.19 & 1.28 & 35 & 51 & .105 \\
\hline-12 & 0.06 & 2.74 & 0.20 & 44 & 42 & .914 \\
\hline-11 & -0.07 & 2.80 & -0.24 & 33 & 53 & .040 \\
\hline-10 & 0.79 & 3.71 & 1.97 & 49 & 37 & .235 \\
\hline-9 & 0.08 & 3.37 & 0.22 & 40 & 46 & .590 \\
\hline
\end{tabular}


Table 4 (cont.). AARs and Z-values - Announcement Day (split ratio 10:2)

\begin{tabular}{|c|c|c|c|c|c|c|}
\hline Event day & AARs (\%) & $\begin{array}{c}\text { Standard } \\
\text { deviation (\%) }\end{array}$ & Z-values* & $\begin{array}{c}\text { Number of } \\
\text { positive ARs }\end{array}$ & $\begin{array}{c}\text { Number of } \\
\text { negative ARs }\end{array}$ & $\begin{array}{l}p \text {-values for the } \\
\text { Proportion Test* }\end{array}$ \\
\hline-8 & 0.45 & 2.89 & 1.45 & 49 & 37 & .235 \\
\hline-7 & 0.36 & 2.80 & 1.21 & 51 & 35 & .105 \\
\hline-6 & 0.63 & 3.02 & 1.95 & 45 & 41 & .747 \\
\hline-5 & 0.78 & 3.50 & 2.06 & 55 & 31 & .013 \\
\hline-4 & 1.06 & 3.72 & 2.63 & 45 & 41 & .747 \\
\hline-3 & 0.39 & 3.99 & 0.90 & 43 & 43 & 1.00 \\
\hline-2 & 0.36 & 3.46 & 0.96 & 43 & 43 & 1.00 \\
\hline-1 & 0.70 & 3.04 & 2.14 & 45 & 41 & .747 \\
\hline 0 & 0.82 & 4.30 & 1.76 & 49 & 37 & .235 \\
\hline+1 & 0.93 & 4.28 & 2.02 & 48 & 38 & .332 \\
\hline+2 & 0.02 & 3.63 & 0.05 & 41 & 45 & .747 \\
\hline+3 & -0.53 & 3.32 & -1.48 & 36 & 50 & .161 \\
\hline+4 & -0.29 & 2.92 & -0.93 & 40 & 46 & .590 \\
\hline+5 & -0.99 & 2.91 & -3.17 & 28 & 58 & .002 \\
\hline+6 & -0.37 & 3.12 & -1.10 & 40 & 46 & .590 \\
\hline+7 & -0.31 & 2.52 & -1.15 & 36 & 50 & .161 \\
\hline+8 & -0.38 & 2.74 & -1.30 & 35 & 51 & .105 \\
\hline+9 & 0.16 & 3.25 & 0.46 & 39 & 47 & .451 \\
\hline+10 & -0.17 & 2.60 & -0.59 & 38 & 48 & .332 \\
\hline+11 & -0.27 & 2.70 & -0.91 & 38 & 48 & .332 \\
\hline+12 & -0.30 & 2.30 & -1.21 & 40 & 46 & .590 \\
\hline+13 & 0.00 & 2.64 & 0.00 & 35 & 51 & .105 \\
\hline+14 & 0.37 & 2.81 & 1.22 & 46 & 40 & .590 \\
\hline+15 & 0.29 & 2.58 & 1.03 & 46 & 40 & .590 \\
\hline+16 & -0.09 & 2.81 & -0.30 & 37 & 49 & .235 \\
\hline+17 & -0.38 & 2.21 & -1.58 & 35 & 51 & .105 \\
\hline+18 & 0.13 & 3.16 & 0.37 & 46 & 40 & .590 \\
\hline+19 & -0.37 & 1.95 & -1.78 & 38 & 48 & .332 \\
\hline+20 & 0.05 & 3.16 & 0.16 & 38 & 48 & .332 \\
\hline
\end{tabular}

Note: * Values in bold are significant at the $5 \%$ significance level.

Table 5. AARs and Z-values - Announcement Day (split ratio 10:5)

Source: Calculated by the authors based on the Prowess IQ database.

\begin{tabular}{|c|c|c|c|c|c|c|}
\hline Event day & AARs (\%) & $\begin{array}{c}\text { Standard } \\
\text { deviation (\%) }\end{array}$ & Z-values* & $\begin{array}{c}\text { Number of } \\
\text { positive ARs }\end{array}$ & $\begin{array}{c}\text { Number of } \\
\text { negative ARs }\end{array}$ & $\begin{array}{l}p \text {-values for the } \\
\text { Proportion Test }\end{array}$ \\
\hline-20 & 1.03 & 3.79 & 1.53 & 17 & 15 & .860 \\
\hline-19 & 2.43 & 4.52 & 3.04 & 22 & 10 & .051 \\
\hline-18 & 1.34 & 4.83 & 1.57 & 19 & 13 & .377 \\
\hline-17 & -0.07 & 4.22 & -0.10 & 20 & 12 & .215 \\
\hline-16 & 0.17 & 3.68 & 0.27 & 13 & 19 & .377 \\
\hline-15 & 0.77 & 4.12 & 1.06 & 18 & 14 & .597 \\
\hline-14 & -0.99 & 5.04 & -1.11 & 16 & 16 & 1.00 \\
\hline-13 & 0.17 & 4.13 & 0.23 & 15 & 17 & .860 \\
\hline-12 & -0.34 & 3.63 & -0.53 & 12 & 20 & .215 \\
\hline-11 & 0.02 & 2.79 & 0.04 & 16 & 16 & 1.00 \\
\hline-10 & 0.08 & 2.64 & 0.18 & 18 & 14 & .597 \\
\hline-9 & -0.18 & 2.73 & -0.37 & 17 & 15 & .860 \\
\hline-8 & 0.39 & 3.44 & 0.64 & 15 & 17 & .860 \\
\hline-7 & 0.37 & 3.07 & 0.69 & 16 & 16 & 1.00 \\
\hline-6 & -0.28 & 3.26 & -0.49 & 16 & 16 & 1.00 \\
\hline-5 & -0.33 & 3.63 & -0.52 & 14 & 18 & .597 \\
\hline-4 & 0.45 & 4.49 & 0.57 & 14 & 18 & .597 \\
\hline
\end{tabular}


Table 5 (cont.). AARs and Z-values - Announcement Day (split ratio 10:5)

\begin{tabular}{|c|c|c|c|c|c|c|}
\hline Event day & AARs (\%) & $\begin{array}{c}\text { Standard } \\
\text { deviation (\%) }\end{array}$ & Z-values* & $\begin{array}{c}\text { Number of } \\
\text { positive ARs }\end{array}$ & $\begin{array}{c}\text { Number of } \\
\text { negative ARs }\end{array}$ & $\begin{array}{l}p \text {-values for the } \\
\text { Proportion Test }\end{array}$ \\
\hline-3 & 1.17 & 4.08 & 1.62 & 21 & 11 & .110 \\
\hline-2 & 0.12 & 3.27 & 0.21 & 14 & 18 & .597 \\
\hline-1 & 0.14 & 3.16 & 0.25 & 16 & 16 & 1.00 \\
\hline 0 & 0.32 & 3.20 & 0.57 & 15 & 17 & .860 \\
\hline+1 & 0.34 & 4.10 & 0.47 & 16 & 16 & 1.00 \\
\hline+2 & -0.38 & 2.87 & -0.74 & 12 & 20 & .215 \\
\hline+3 & -0.50 & 3.46 & -0.82 & 13 & 19 & .377 \\
\hline+4 & 0.32 & 3.92 & 0.46 & 13 & 19 & .377 \\
\hline+5 & -0.10 & 3.26 & -0.18 & 18 & 14 & .597 \\
\hline+6 & -0.27 & 3.04 & -0.51 & 13 & 19 & .377 \\
\hline+7 & -0.71 & 2.90 & -1.38 & 12 & 20 & .215 \\
\hline+8 & 0.07 & 3.91 & 0.10 & 17 & 15 & .860 \\
\hline+9 & -0.35 & 3.57 & -0.55 & 12 & 20 & .215 \\
\hline+10 & -1.03 & 3.33 & -1.75 & 12 & 20 & .215 \\
\hline+11 & -0.48 & 3.01 & -0.90 & 11 & 21 & .110 \\
\hline+12 & -0.19 & 3.14 & -0.34 & 15 & 17 & .860 \\
\hline+13 & 0.12 & 3.47 & 0.19 & 15 & 17 & .860 \\
\hline+14 & 0.81 & 3.89 & 1.18 & 17 & 15 & .860 \\
\hline+15 & 0.74 & 2.57 & 1.63 & 17 & 15 & .860 \\
\hline+16 & 0.20 & 3.31 & 0.33 & 15 & 17 & .860 \\
\hline+17 & -0.95 & 3.35 & -1.60 & 8 & 24 & .007 \\
\hline+18 & 0.22 & 3.09 & 0.41 & 16 & 16 & 1.00 \\
\hline+19 & -0.31 & 3.67 & -0.48 & 14 & 18 & .597 \\
\hline+20 & -0.55 & 3.27 & -0.94 & 13 & 19 & .377 \\
\hline
\end{tabular}

Note: * Values in bold are significant at the $5 \%$ significance level.

AARs for three split ratio groups, when plotted on a graph, are in Figure 3. Negative AARs start for the stock split ratios of 10:2 and 10:1 on the same event day, that is, $t_{+2}$ day, while negative AARs start for the split ratio 10:5 on $t_{+1}$ day.

To further analyze AARs, ASARs are calculated using equations (6) and (7). To test the statistical significance of ASARs, $Z_{s}$-test is performed using equation (8). The null hypothesis tested is that ASARs on an event day is equal to zero. Table 6 shows that ASARs with significant $Z_{s}$-values at the $5 \%$ significance level are present for six days (split ratio 10:1), eight days (split ratio 10:2) and two days (split ratio 10:5).

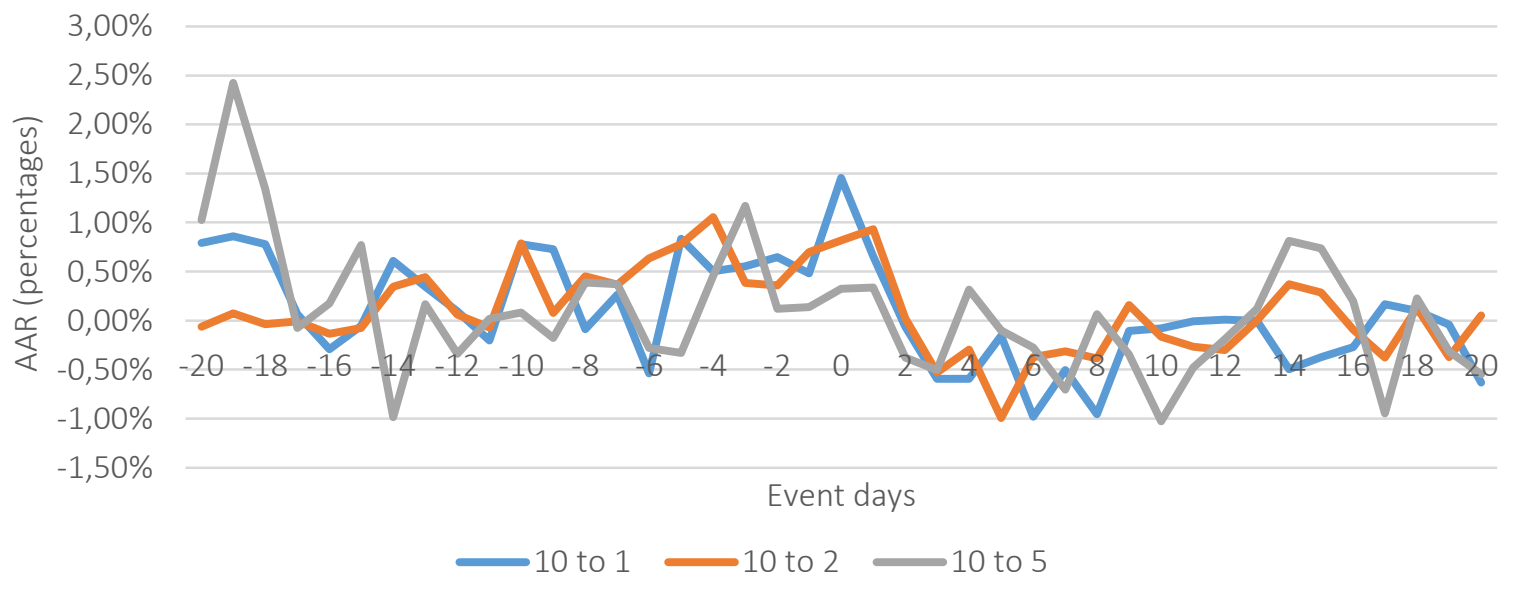

Figure 3. AARs - Announcement Day (different stock split ratios) 
Table 6. AARs and $Z_{\mathrm{s}}$-values - Announcement Day (different stock split ratios)

Source: Calculated by the authors based on the Prowess IQ database.

\begin{tabular}{|c|c|c|c|c|c|c|}
\hline 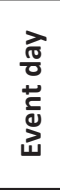 & $\frac{\stackrel{+}{0}}{\stackrel{-1}{\circ}}$ & 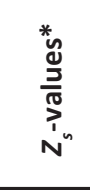 & 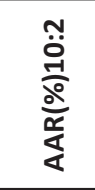 & 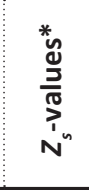 & 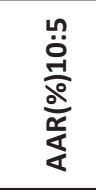 & 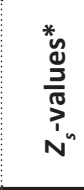 \\
\hline-20 & 0.79 & 2.42 & -0.06 & 0.23 & 1.03 & 1.27 \\
\hline-19 & 0.86 & 1.22 & 0.07 & -0.19 & 2.43 & 3.73 \\
\hline-18 & 0.78 & 0.97 & -0.04 & -0.10 & 1.34 & 1.90 \\
\hline-17 & 0.06 & 0.04 & -0.01 & 0.19 & -0.07 & 0.32 \\
\hline-16 & -0.29 & -0.06 & -0.13 & -1.16 & 0.17 & -0.21 \\
\hline-15 & -0.05 & -0.24 & -0.07 & -0.64 & 0.77 & 0.90 \\
\hline-14 & 0.61 & 1.20 & 0.35 & 1.77 & -0.99 & -1.12 \\
\hline-13 & 0.35 & 1.31 & 0.44 & 0.47 & 0.17 & 0.09 \\
\hline-12 & 0.10 & 0.76 & 0.06 & 0.30 & -0.34 & -0.21 \\
\hline-11 & -0.20 & -0.88 & -0.07 & -0.32 & 0.02 & 0.08 \\
\hline-10 & 0.78 & 1.04 & 0.79 & 2.37 & 0.08 & 0.06 \\
\hline-9 & 0.73 & 0.68 & 0.08 & 0.40 & -0.18 & -0.09 \\
\hline-8 & -0.09 & -0.01 & 0.45 & 0.94 & 0.39 & 0.79 \\
\hline-7 & 0.26 & 0.19 & 0.36 & 1.10 & 0.37 & 0.51 \\
\hline-6 & -0.54 & -1.16 & 0.63 & 2.37 & -0.28 & -0.34 \\
\hline-5 & 0.84 & 2.76 & 0.78 & 3.75 & -0.33 & -0.31 \\
\hline-4 & 0.50 & 1.06 & 1.06 & 2.42 & 0.45 & 1.07 \\
\hline-3 & 0.55 & 1.13 & 0.39 & 0.51 & 1.17 & 2.08 \\
\hline-2 & 0.65 & 1.24 & 0.36 & 0.63 & 0.12 & -0.17 \\
\hline-1 & 0.48 & 1.43 & 0.70 & 1.46 & 0.14 & 0.70 \\
\hline 0 & 1.45 & 3.35 & 0.82 & 3.12 & 0.32 & 0.26 \\
\hline+1 & 0.66 & 1.58 & 0.93 & 3.62 & 0.34 & 0.33 \\
\hline+2 & -0.06 & -0.76 & 0.02 & 0.57 & -0.38 & -0.79 \\
\hline+3 & -0.59 & -1.47 & -0.53 & -2.02 & -0.50 & -0.26 \\
\hline+4 & -0.59 & -2.12 & -0.29 & -0.74 & 0.32 & 1.23 \\
\hline+5 & -0.16 & 0.12 & -0.99 & -2.78 & -0.10 & 0.32 \\
\hline+6 & -0.98 & -2.49 & -0.37 & -1.24 & -0.27 & -0.33 \\
\hline+7 & -0.51 & -1.27 & -0.31 & -0.81 & -0.71 & -1.25 \\
\hline+8 & -0.95 & -2.49 & -0.38 & -1.13 & 0.07 & -0.26 \\
\hline+9 & -0.11 & 0.02 & 0.16 & 0.79 & -0.35 & -0.81 \\
\hline+10 & -0.08 & -0.35 & -0.17 & -0.25 & -1.03 & -1.12 \\
\hline+11 & -0.01 & -0.22 & -0.27 & -0.92 & -0.48 & -1.10 \\
\hline+12 & 0.01 & -0.85 & -0.30 & -0.93 & -0.19 & -0.31 \\
\hline+13 & 0.00 & -0.46 & 0.00 & -0.50 & 0.12 & 0.15 \\
\hline+14 & -0.49 & -1.50 & 0.37 & 0.93 & 0.81 & 0.78 \\
\hline+15 & -0.37 & -1.05 & 0.29 & 0.98 & 0.74 & 1.52 \\
\hline+16 & -0.27 & -0.97 & -0.09 & 0.06 & 0.20 & -0.07 \\
\hline+17 & 0.17 & -0.25 & -0.38 & -1.25 & -0.95 & -1.31 \\
\hline+18 & 0.10 & 0.03 & 0.13 & 0.62 & 0.22 & 0.28 \\
\hline+19 & -0.04 & 0.06 & -0.37 & -0.79 & -0.31 & -0.09 \\
\hline+20 & -0.63 & -0.92 & 0.05 & 0.10 & -0.55 & -1.17 \\
\hline
\end{tabular}

Note: * Values in bold are significant at the $5 \%$ significance level.

\subsection{Impact on CAAR - Announcement Day (different stock split ratios)}

To examine a cumulative effect of stock splits on AARs, cumulative average abnormal returns (CAARs) are calculated to analyze a cumulative effect of AARs using cumulative average abnormal returns (CAARs).

Table 7. CAARs and $Z_{\text {cs }}$ values - Announcement Day (different split ratios)

Source: Calculated by the authors based on the Prowess IQ database.

\begin{tabular}{|c|c|c|c|c|c|c|}
\hline 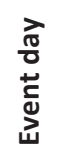 & 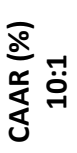 & $\begin{array}{l}\stackrel{*}{y} \\
\frac{d}{3} \\
\sum^{\frac{1}{0}} \\
N^{y}\end{array}$ & 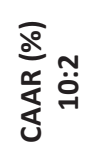 & 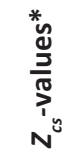 & 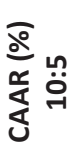 & $\frac{{ }^{*}}{\frac{d}{\partial}}$ \\
\hline-20 & 0.79 & 0.38 & -0.06 & 0.04 & 1.03 & 0.20 \\
\hline-19 & 1.65 & 0.57 & 0.01 & 0.01 & 3.45 & 0.78 \\
\hline-18 & 2.43 & 0.72 & -0.03 & -0.01 & 4.79 & 1.08 \\
\hline-17 & 2.50 & 0.73 & -0.03 & 0.02 & 4.72 & 1.13 \\
\hline-16 & 2.21 & 0.72 & -0.17 & -0.16 & 4.89 & 1.10 \\
\hline-15 & 2.15 & 0.68 & -0.24 & -0.26 & 5.66 & 1.24 \\
\hline-14 & 2.76 & 0.87 & 0.11 & 0.02 & 4.67 & 1.06 \\
\hline-13 & 3.11 & 1.07 & 0.55 & 0.09 & 4.84 & 1.08 \\
\hline-12 & 3.20 & 1.19 & 0.61 & 0.14 & 4.50 & 1.04 \\
\hline-11 & 3.00 & 1.06 & 0.53 & 0.09 & 4.52 & 1.06 \\
\hline-10 & 3.78 & 1.22 & 1.32 & 0.46 & 4.60 & 1.07 \\
\hline-9 & 4.51 & 1.32 & 1.40 & 0.52 & 4.43 & 1.05 \\
\hline-8 & 4.42 & 1.32 & 1.85 & 0.66 & 4.82 & 1.18 \\
\hline-7 & 4.68 & 1.35 & 2.22 & 0.84 & 5.19 & 1.26 \\
\hline-6 & 4.15 & 1.17 & 2.85 & 1.21 & 4.91 & 1.20 \\
\hline-5 & 4.98 & 1.60 & 3.63 & 1.79 & 4.58 & 1.15 \\
\hline-4 & 5.49 & 1.77 & 4.68 & 2.17 & 5.03 & 1.32 \\
\hline-3 & 6.04 & 1.95 & 5.07 & 2.25 & 6.20 & 1.65 \\
\hline-2 & 6.69 & 2.14 & 5.43 & 2.35 & 6.32 & 1.62 \\
\hline-1 & 7.17 & 2.36 & 6.13 & 2.58 & 6.46 & 1.73 \\
\hline 0 & 8.62 & 2.89 & 6.94 & 3.06 & 6.78 & 1.77 \\
\hline+1 & 9.28 & 3.13 & 7.88 & 3.63 & 7.12 & 1.82 \\
\hline+2 & 9.22 & 3.01 & 7.90 & 3.72 & 6.75 & 1.70 \\
\hline+3 & 8.62 & 2.78 & 7.37 & 3.40 & 6.24 & 1.66 \\
\hline+4 & 8.03 & 2.45 & 7.07 & 3.29 & 6.56 & 1.85 \\
\hline+5 & 7.87 & 2.47 & 6.08 & 2.85 & 6.46 & 1.90 \\
\hline+6 & 6.89 & 2.08 & 5.71 & 2.66 & 6.18 & 1.85 \\
\hline+7 & 6.39 & 1.88 & 5.39 & 2.53 & 5.48 & 1.65 \\
\hline+8 & 5.43 & 1.50 & 5.01 & 2.36 & 5.54 & 1.61 \\
\hline+9 & 5.33 & 1.50 & 5.17 & 2.48 & 5.19 & 1.49 \\
\hline+10 & 5.25 & 1.44 & 5.00 & 2.44 & 4.17 & 1.31 \\
\hline+11 & 5.24 & 1.41 & 4.73 & 2.30 & 3.69 & 1.14 \\
\hline+12 & 5.25 & 1.28 & 4.44 & 2.15 & 3.50 & 1.09 \\
\hline+13 & 5.25 & 1.20 & 4.43 & 2.07 & 3.61 & 1.12 \\
\hline+14 & 4.75 & 0.97 & 4.80 & 2.22 & 4.43 & 1.24 \\
\hline+15 & 4.38 & 0.81 & 5.09 & 2.37 & 5.16 & 1.47 \\
\hline+16 & 4.11 & 0.65 & 5.00 & 2.38 & 5.36 & 1.46 \\
\hline+17 & 4.28 & 0.62 & 4.62 & 2.18 & 4.41 & 1.26 \\
\hline+18 & 4.37 & 0.62 & 4.75 & 2.28 & 4.64 & 1.30 \\
\hline+19 & 4.33 & 0.63 & 4.38 & 2.16 & 4.32 & 1.29 \\
\hline+20 & 3.70 & 0.49 & 4.43 & 2.17 & 3.78 & 1.11 \\
\hline
\end{tabular}

Note: * Values in bold are significant at the $5 \%$ significance level. 


\section{CAAR}

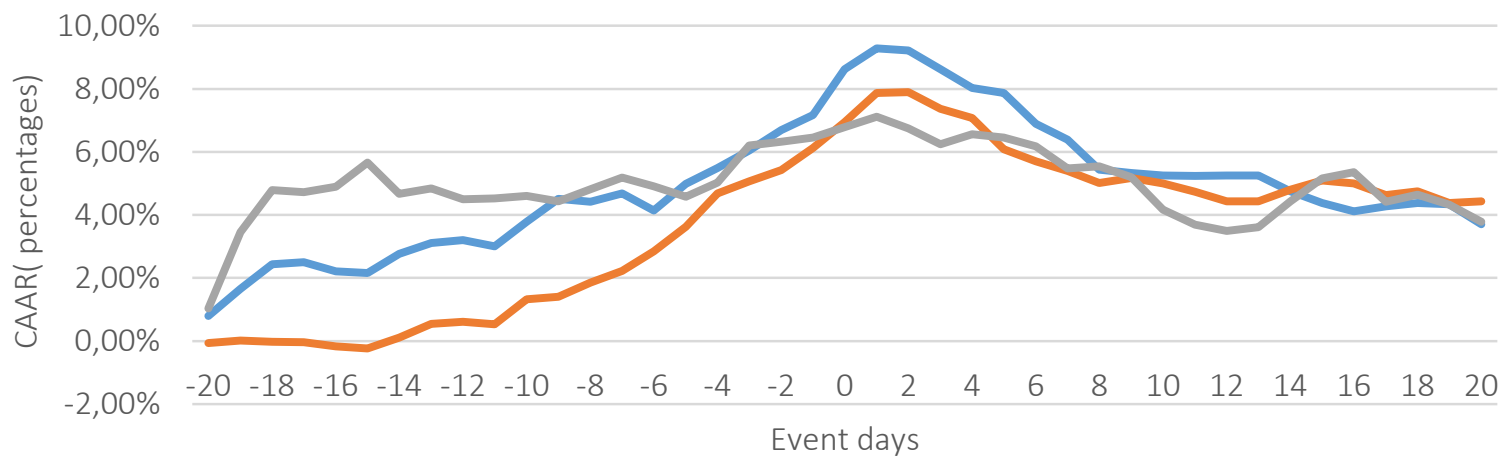

10 to $1-10$ to $2=10$ to 5

Figure 4. CAARs - Announcement Day (different stock split ratios)

Comparative CAARs plotted show that CAARs are positive for all split ratios in the announcement window (see Figure 4). The returns are higher for split ratios 10:1 and 10:2 as compared to the split ratio of 10:5.

CAARs are also aggregated for different time periods in the 41-day event window. The null hypothesis tested using $Z_{c s}$-test is that CAAR is zero at the end of the period over which cumulated. Table 8 shows that the null hypothesis is not accepted, and there are significant $Z_{c s}$-values for the split ratio of 10:1 for event windows extended to $t_{-5}$ to $t_{+5}$ days. The null hypothesis is not accepted, and significant $Z_{c s}$-values are present for all event windows of different days in the 41-day period for the split ratio 10:2. For the split ratio 10:5, null hypothesis is not rejected in any event window.

\section{DISCUSSION}

There is a significant increase in AARs for all selected companies on days $-t_{-20}, t_{-19}, t_{-5}, t_{-4}$ and $t_{-3}$, which could mean information leakage prior to the official announcement of the stock split by a company or insider trading. Grinblatt, Masulis, and Titman (1984), Ikenberry and Ramnath (2002) and Fama (1970) have also suggested the leak as possible reasons for significant positive AARs before the announcement day. For all sampled companies during the pre-announcement window, CAAR increases significantly from $0.50 \%$ to $6.35 \%$. After the announcement day, CAAR shows a declining trend. CAAR of $7.75 \%$ on $t_{+1}$ day declines to $2.58 \%$ by $t_{+20}$. This means that the market initially responds positively to stock splits but corrects prices downward soon after the announcement day. Insider trading can also be a reason for significant CAARs in the event period from $t_{-10}$ to $t_{+10}$ days. The result is in line with Liu, Smith, and Side (1990), Beneish (1991), and Kiymez (1999).

AARs for the group of companies with stock split ratio of 10:1 increase for six days starting from day $t_{-4}$. This increase continues till $t_{+1}$ day in the announcement window. After

Table 8. CAARs and $Z_{c s}$-values - Announcement Day (41-day event window: different split ratios)

Source: Calculated by the authors based on the Prowess IQ database.

\begin{tabular}{|c|c|c|c|c|c|c|c|}
\hline Event days & No. of days & CAAR (\%) 10:1 & $Z_{c s}$-values* & CAAR (\%) 10:2 & $Z_{c s}$-values* & CAAR (\%) 10:5 & $Z_{c s}$-values* \\
\hline-20 to 20 & 41 & 3.70 & 0.49 & 4.43 & 2.17 & 3.78 & 1.11 \\
\hline-10 to 10 & 21 & 2.25 & 0.54 & 4.47 & 3.29 & -0.35 & 0.36 \\
\hline-5 to +5 & 11 & 3.73 & 2.51 & 3.23 & 3.18 & 1.55 & 1.35 \\
\hline-2 to +2 & 5 & 3.18 & 3.06 & 2.83 & 4.20 & 0.54 & 0.15 \\
\hline-2 to 0 & 3 & 2.59 & 3.48 & 1.88 & 3.01 & 0.58 & 0.46 \\
\hline 0 to +2 & 3 & 2.05 & 2.41 & 1.77 & 4.22 & 0.29 & -0.11 \\
\hline-1 to +1 & 3 & 2.59 & 3.68 & 2.45 & 4.73 & 0.80 & 0.75 \\
\hline
\end{tabular}

Note: * Values in bold are significant at $5 \%$ level of significance. 
$t_{+1}$ day, AARs start decreasing and are negative from $t_{+2}$ day for 19 days. Positive AARs with significant $Z$-values are observed on day $t_{0}$. Negative AARs with significant $Z$-value are noted on days $-t_{+6}$ and $t_{+8}$. The companies in the sample, which have announced stock splits in the ratio of $10: 2$, show positive AARs on days $t_{-5}, t_{-4}, t_{-1}$, and $t_{+1}$ with significant $Z$-values at the $5 \%$ significance level. There are negative AARs on day $t_{+5}$ with significant $Z$-value at the $5 \%$ level of significance. The companies that have announced stock splits in the ratio of 10:5 then have AARs consistently increasing and positive for four days, from $t_{-4}$ to $t_{+1}$. Positive AAR with significant $Z$-value is observed only for $t_{-19}$ day. To further analyze AARs, ASARs are calculated using the equation, and to test the statistical significance of ASARs, $Z$-test is performed using the equation. The null hypothesis tested is that ASARs on an event day equal zero. It is observed that
ASARs with significant $Z$-values at the $5 \%$ level of significance are present for six days (split ratio 10:1), eight days (split ratio 10:2) and two days (split ratio 10:5).

To examine a cumulative effect of stock splits on AARs, Cumulative Average Abnormal Returns (CAARs) are calculated using cumulative average abnormal returns (CAARs). Comparative CAARs' values are positive for all split ratios in the announcement window. The returns are higher for split ratios 10:1 and 10:2 as compared to the split ratio 10:5. CAARs are also aggregated for different time periods in the event window of 41 days. The null hypothesis is tested using $Z_{c s}$-test, and significant $Z_{c s}$-values are present for the split ratio 10:1 for the event windows extended from $t_{-5}$ to $t_{+5}$ days. Significant $Z_{c s}$-values are present for all event windows of different days in the 41-day period for split ratio 10:2.

\section{CONCLUSION}

The aim of this study was to investigate the impact of stock splits around the announcement day with particular emphasis on finding any differences in the impact with differences in the stock split ratios. The analysis shows that AARs are significantly positive on the announcement day. It is suggested that almost equal immediate positive effects on share prices and firm value are present for all split ratios. There is no long-term effect of stock splits on share prices around the announcement day, as the period of significant CAARs is not extended beyond $t_{+10}$ day. Significant CAARs in the pre-announcement window imply that there is information leakage prior to stock split announcements. This implication is drawn from the semi-strong form of efficient market ${ }^{6}$ hypothesis. The analysis of AARs and CAARs for different stock splits ratios shows that the impact on AARs is stronger for companies with split ratios 10:1 and 10:2 in the announcement window. For companies with a split ratio of 10:5, there is no such strong evidence. One can also conclude that 10:1 and 10:2 are the most popular split ratios that get a maximum ongoing response to splits in the announcement window. Thus, it can be assumed that a higher split factor results in higher returns after the stock split, which is in line with the results reported by Kuse and Yamamato (2004). For the lowest split ratio in the announcement window, there is no effect on ARs. This is emphasized by both AARs, CAARs and their significance values. The results support the views of McNichols and Dravid ${ }^{7}$ (1990). Thus, it can be concluded that the graphical presentation or empirical results reported in the tables suggest that the impact on ARs is greater in case of higher split ratios in the announcement window.

\section{AUTHOR CONTRIBUTIONS}

Conceptualization: Dr. Anjali Gupta.

Data curation: Dr Anjali Gupta, Dr Purushottam Kumar Arya

6 According to the semi-strong form of the efficient market, if there is leakage of information before a corporate announcement, then CAARs will gradually increase in pre-announcement window and decrease on announcement day because of the response of companies for which information did not leak.

$7 \quad$ McNichols and Dravid (1990) reported that the higher split ratio is announced when there are higher expectations of future performance. The higher split ratio has a more positive impact on ARs and share prices. 
Formal analysis: Dr Anjali Gupta, Dr Purushottam Kumar Arya

Investigation: Dr Anjali Gupta, Dr Purushottam Kumar Arya

Methodology: Dr Anjali Gupta, Dr Purushottam Kumar Arya.

Visualization: Dr Anjali Gupta, Dr Purushottam Kumar Arya.

Writing - original draft: Dr Anjali Gupta.

Writing - review \& editing: Dr Purushottam Kumar Arya.

\section{REFERENCES}

1. Acharya, A. (1993). Value of latent information: alternative event study methods. Journal of Finance, 48(1), 363-386. https:// doi.org/10.1111/j.1540-6261.1993. tb04715.x

2. Amihud, Y., Mendelson, H., \& Pedersen, L. H. (2005). Liquidity and asset prices. Foundations and Trends in Finance, 1(4), 269-364. Retrieved from https://papers.ssrn.com/sol3/ papers.cfm?abstract_id=1625020

3. Anshuman, V., \& Kalay, A. (2002). Can Splits Create Market Liquidity: Theory and Evidence. Journal of Financial Markets, 5, 83-125. Retrieved from http://dl.fxf1.com/ files/books/english/Anshumana\%20 And\%20Kalay-Can\%20Splits\%20 Create\%20Market\%20Liquidity\%20 -\%20Theory\%20And\%20Evidence. pdf

4. Bhuvaneshwari, D., \& Ramya, K. (2014). Impact of stock split announcement on stock prices. International Journal of Management, 5(3), 36-46. Retrieved from https:// www.academia.edu/6654178/IMPACT_OF_STOCK_SPLIT_ANNOUNCEMENT_ON_STOCK_ PRICES

5. Biger, N., \& Page, M. (1992). The market reaction to stock splits and capitalization issues: Recent JSE experience. Journal of Studies in Economics and Econometrics, 161165.

6. Binder, J. J. (1988). The event study methodology since 1969. Review of Quantitative Finance and Accounting, 11, 111-137. https://doi. org/10.1023/A:1008295500105

7. Brennan, M. J., \& Hughes, P. J. (1991). Stock Prices and Supply of Information. Journal of Finance 46(5), 1665-1691. https://doi. org/10.1111/j.1540-6261.1991. tb04639.x
8. Brennan, M., \& Copeland, T. (1988). Stock splits, stock prices and transaction costs. Journal of Financial Economics, 22(1), 83101. https://doi.org/10.1016/0304405X(88)90023-2

9. Brigham, E. (1989). Fundamentals of Financial Management (5th ed.). The Dryden Press.

10. Brown, S., \& Goetzmann, W. (1995). Performance Persistence. Journal of Finance, 50(2), 679-698. https://doi. org/10.1111/j.1540-6261.1995. tb04800.x

11. Brown, S., \& Warner, J. B. (1980). Measuring Security Price Performance. Journal of Financial Economics, 8(3), 205-258. https://doi.org/10.1016/0304405X(80)90002-1

12. Brown, S., \& Warner, J. B. (1985). Using Daily stock returns the case of Event studies. Journal of Financial Economics, 14(1), 3-31. https://doi.org/10.1016/0304405X(85)90042-X

13. Budhraja, I., Parekh, P., \& Singh, T. (2003). Empirical Study on Market Reaction Around the Bonus and Stock Split. Mudra SIGFI IIML Journal of Finance, 2.

14. Chakraborty, M. (2012). The Equity Market around the ExSplit Date: Evidence from India. Vikalpa, 37(1), 57-69. https://doi. org/10.1177/0256090920120105

15. Chakraborty, P. (2011). Semi strong form of pricing efficiency of Indian stock market - a empirical test in the context of stock-split announcements. EXCEL International Journal of Multidisciplinary Management studies, 1(2), 1-13. Retrieved from http://www.zenithresearch.org. in/images/stories/pdf/2011/Nov/
EIJMMS/1_EIJMMS_VOL1_ISSUE2.pdf

16. Conroy, R., \& Harris, R. (1999). Stock Splits and Information: The Role of Share Price. Financial Management, 28(3), 28-40. Retrieved from https://www.jstor. org/stable/3666181

17. Copeland, T. E. (1979). Liquidity Changes Following Stock Splits. Journal of Finance, 34(1), 115-141. https://doi. org/10.1111/j.1540-6261.1979. tb02075.x

18. Dhar, S., \& Chhacohharia, S (2009). Market reaction around the stock splits and Bonus issues: Some Indian Evidence Portfolio Organizer. ICFAI University Press. Retrieved from https://papers.ssrn. $\mathrm{com} /$ sol3/papers.cfm?abstract_ $\mathrm{id}=1087200$

19. Dimson, E., \& Marsh, P. (1986). Event study methodologies and the size effect. Journal of Financial Economics, 17(1), 113-142. https://doi.org/10.1016/0304405X(86)90008-5

20. Dodd, P., \& Warner, J. (1983). On Corporate Governance A Study of Proxy Contests. Journal of Financial Economics, 11(1-4), 401438. https://doi.org/10.1016/0304405X(83)90018-1

21. Fama, E. F. (1970). Efficient Capital Markets- A Review of theory and Empirical Work. Journal of Finance, 25(2), 383-417. https://doi. org/10.1111/j.1540-6261.1970 tb00518.x

22. Ghatak, A. (2011). Capital Market Reaction around the Stock Splits and Bonus Issues: Evidence from Some Indian IT Stocks. The International Journal - Research Journal of Social Science and 
Management, 1(5), 191-208. Retrieved from https://www. semanticscholar.org/paper/ Capital-Market-Reaction-Aroundthe-Stock-Splits-and-Ghatak/252 7150f931ea8dc4921325eb1458186 d4bf9b80

23. Grinblatt, M. S., Masulis, R. W., \& Titman, S. (1984). The Valuation Effects of Stock-Splits and Stock Dividends. Journal of Financial Economics, 13(4), 461-490. https://doi.org/10.1016/0304405X(84)90011-4

24. Guo, F., Zhou, K., \& Cai, J. (2008). Stock splits, liquidity and information asymmetry - An empirical study on Tokyo Stock Exchange. Financial Management, 22(3), 417-438. https://doi. org/10.1016/j.jjie.2008.01.002

25. Gupta, A., \& Gupta, O. P. (2007). Market Reaction to Stock Splits: Evidence from India. The IUP Journal of Applied Finance, 13(1), 5-22. Retrieved from https:// www.researchgate.net/publication/215527029_Market_Reaction_to_Stock_Market_Splits_Evidence_from_India

26. Gupta, C. P., \& Kumar, R. (2007). A Re-examination of factors affecting returns in the Indian stock market. Journal of Finance, 3, 20-24. Retrieved from https:// papers.ssrn.com/sol3/papers. cfm?abstract $\_$id $=1376236$

27. Huang, G. C., Liano, K., \& Pan, M. S. (2015). The effects of stock splits on stock liquidity. Journal of Economics and Finance, 39(1), 119-135. https://doi.org/10.1007/ s12197-013-9250-6

28. Ikenberry, D. L., \& Ramnath, S. (2002). Under reaction to Selfselected News Events: The Case of Stock Split. Review of Financial Studies, 15(2), 489-526. Retrieved from https://ideas.repec.org/a/ oup/rfinst/v15y2002i2p489-526. html

29. Jaffi, J. (1974). Special Information and Insider Trading. Journal of Business, 47(3), 410-428. http:// dx.doi.org/10.1086/295655

30. Kothari, C. R. (2004). Research Methodology (2th ed). New Delhi: New Age International (P)Ltd.
31. Kumar, S. and Halageri, S. (2011), "Impact of Stock Split announcement on stock price", Review of Management, Volume I, No. 1, Jan - Mar, pg. 15-32.

32. Kumar, S. M. (2014). Share split and stock market efficiency in India. Zenith International Journal of Multidisciplinary Research, 4(6), 23-34. Retrieved from http://www. zenithresearch.org.in/images/stories/pdf/2014/JUNE/ZIJMR/3_ZIJMR_VOL4_ISSUE6_JUNE2014. pdf

33. Kuse, Y., \& Yamamoto, T. (2004). Stock Price Anomalies Subsequent to Stock Split Announcements: Japanese Evidences. Retrieved from http://ssrn.com/abstract $=1101210$

34. Lakonishok, J., \& Lev, B. (1987). Stock Splits and Stock Dividends: Why, Who and When. Journal of Finance, 42(4), 913-932. Retrieved from https://econpapers.repec.org/ article/blajfinan/v_3a42_3ay_3a19 87_3ai_3a4_3ap_3a913-32.htm

35. Lamoureux, C. G., \& Poon, P. (1987). The Market reaction to Stock Splits. Journal of Finance, 45 , 1347-1370.

36. Lo, \& Mc Kinley. (2004). Event study analysis- Chapter 4. Book of Financial Economics.

37. McNicholas, M., \& Dravid, A. (1990). Stock dividends, stock splits, and signaling. Journal of Finance, 45(3), 857-879. https:// doi.org/10.1111/j.1540-6261.1990. tb05109.x

38. Mishra, A. K. (2007). The Market Reaction to Stock Splits-Evidence from India. International Journal of Theoretical and Applied Finance, 10(2), 251-271. https://doi. org/10.1142/S0219024907004226

39. Raju, M. T., \& Ghosh, A. (2004). Stock Market Volatility - An International Comparison (SEBI Working Paper Series No. 8). Retrieved from https://www. mmimert.edu.in/images/digitallibrary/Stock-Market-VolatilityInternational-Comparison.pdf

40. Savitri, M., \& Martani, D. (2008). The Analysis Impact of Stock Split on Stock Return and Volume -The Case of Jakarta Stock Exchange. Journal of Finance, 2, 25-27.
41. Singh ,S., \& Supna ,K.( 2013). Efficiency of Indian stock market: Evidences based on Stock Splits. International Journal of Rese arch in Computer Application and Management, 3 (7), 12 - 21.

42. Suresha, B., \& Naidu, G. (2013). An empirical study on price pressures and liquidity effects of stock split announcement evidence from Indian market. International Journal of Marketing and Technology, 3(1), 138-156. Retrieved from https://www. indianjournals.com/ijor.aspx?targ et $=$ ijor $:$ ijmt $\&$ volume $=3 \&$ rissue $=1 \&$ article $=009$

43. Tantia, V., \& Sebastian, S. (2012). Impact of Stock Split on Return - An Empirical Study of selected NSE companies. Golden Research Thoughts, 1-8.

44. Thirunellai, S. (2013). Stock Splits: Reasons and valuation effects. PGPM Program with NSE, S. P. Jain Institute of Management \& Research.

45. Wong ShouWoon. (2002). Introduction to the Event Study Methodology. Singapore: Singapore Management University.

46. Xiao-Xuan, Y. (2013). The Market Reaction to Stock Splits Used as Dividends. Technology and Investment, 4, 42-53. http://dx.doi. org/10.4236/ti.2013.41B009 